\title{
PROBLEM INTERPRETACJI W NAUKACH HUMANISTYCZNYCH (NA PRZYKEADZIE STRUKTURALIZMU EDMUNDA LEACHA)
}

\section{WPROWADZENIE}

W niniejszym artykule ${ }^{1}$ zajmuję się problemem strukturalistycznej interpretacji kultury w naukach humanistycznych. Z oczywistych względów ograniczam pole swoich badań do wybranego przykładu interpretacji strukturalistycznej. Przedmiotem analizy jest tekst brytyjskiego antropologa kultury, Edmunda Leacha (1910-1989): Przeciw podziałowi na gatunki: czy przypowieści stawiaja światło na świeczniku, czy ukrywaja je pod korcem ${ }^{2}$

Celem artykułu jest uzyskanie odpowiedzi na następujące pytania:

1. Jaką metodę badawczą deklaruje Edmund Leach?

${ }^{1}$ Niniejszy artykuł jest nieznacznie zmienioną wersją pracy licencjackiej, napisanej pod kierunkiem ks. dr. Zbigniewa Liany, obronionej w 2010 r. na Wydziale Filozoficznym Uniwersytetu Papieskiego Jana Pawła II w Krakowie.

${ }^{2}$ E. Leach, Przeciw podziałowi na gatunki: czy przypowieści stawiaja światło na świeczniku, czy ukrywaja je pod korcem?, [w:] E. Leach, A.D. Aycock, Siostra Mojżesza. Strukturalistyczne interpretacje mitu biblijnego, przeł. M. Buchowski, H. Burszta, W.J. Burszta, Wydawnictwo Zysk i Spółka, Poznań 1998. 
2. Czy badania Leacha nad tekstami ewangelicznymi zostały przeprowadzone zgodnie $\mathrm{z}$ deklarowaną przezeń metodą badawczą?

3. Jaką wartość wykazuje praca Leacha z punktu widzenia filozofii nauki?

Niniejszy artykuł składa się z trzech części. W pierwszej z nich zajmuję się rozważaniami metodologicznymi prowadzonymi przez Leacha. Staram się określić, co badacz rozumie pod pojęciem metody strukturalnej. Wskazuję na najważniejsze elementy leachowskiej koncepcji: cele badawcze, tezy, założenia, definicje terminów: struktura, transformacja strukturalna, mit, rytuał, postulowane narzędzie badawcze - schemat "rites de passage" van Gennepa. Jednocześnie staram się wskazywać na momenty, w których Leach wykracza poza uprawnienia antropologa. W drugiej części artykułu zajmuję się przykładem konkretnej analizy strukturalnej dokonanej przez Leacha, to jest analizy strukturalnej Ewangelii w oparciu o schemat van Gennepa. Relacjonuję kolejne kroki postępowania badawczego, sprawdzając, czy badacz nie wykracza poza zasady strukturalizmu, wyznaczone w metodologicznej części tekstu. W ostatniej, trzeciej części artykułu wskazuję na najbardziej dyskusyjne momenty zarówno koncepcji metody strukturalnej, jak i konkretnego zastosowania tej metody w tekście Leacha. Staram się odpowiedzieć na pytanie, jaką wartość poznawczą posiadają badania strukturalne, prowadzone przez Leacha z punktu widzenia filozofii nauki.

Edmund Leach jest jednym z licznych reprezentantów strukturalizmu w badaniach nad kulturą. Sam strukturalizm, nawet jeżeli wziąć pod uwagę wyłącznie nauki humanistyczne, skupia przedstawicieli licznych dziedzin. Pośród nich znajdują się: językoznawcy, antropolodzy kultury, literaturoznawcy, filozofowie, 
psycholodzy, socjolodzy, religioznawcy, historycy, historycy sztuki. Niełatwe jest zdefiniowanie, czym jest strukturalizm, zarówno w jego warstwie „formalnej”, jak „materialnej”. Bywa bowiem strukturalizm zarówno metodą badawczą, jak i interpretacją kultury. Podobnie nie ma zgody co do tego, co jest istotą strukturalizmu. Oczywiście nazwa tego kierunku badawczego w antropologii wywodzi się od pojęcia struktury, rozumianej jako to, co trwałe, niezmienne, głębokie, abstrakcyjne - w opozycji do tego, co nietrwałe, zmienne, powierzchniowe, konkretne. Zdaniem strukturalistów, struktury wyrażają się poprzez wszelkie zjawiska kultury: język, mity, religię, obyczaje etc., aczkolwiek tylko niektórzy z badaczy, jak choćby Claude Lévi-Strauss, skłonni są twierdzić, iż struktury te są odzwierciedleniem struktur ludzkiego umysłu ${ }^{3}$. Badaczy różni także stopień abstrakcyjności, jaki gotowi są przypisać strukturom. Jak pisze Gabriela Augustynowicz, „Przypomina to nieco poszukiwanie w genotypie danego osobnika zespołu genów generujących odpowiednio cechy osobnicze, gatunkowe, rasowe"4. Również nie ma jednoznacznej odpowiedzi na wiele innych pytań, które można postawić strukturalistom. Jest więc strukturalizm zespołem różnych metod i teorii w badaniach nad kulturą, które łączy to, iż posługują się pojęciem struktury w wyżej zarysowanym rozumieniu.

Najważniejszym przedstawicielem strukturalizmu w etnologii był Claude Lévi-Strauss (1908-2009), twórca antropologii strukturalnej. Jego badania wspierały się na pracach Émile’a Durkheima

${ }^{3}$ Zob. E. Krawczak, Antropologia kulturowa: klasyczne kierunki, szkoły i orientacje, Wydawnictwo Uniwersytetu Marii Curie-Skłodowskiej, Lublin 2004, s. 129-135.

${ }^{4}$ G. Augustynowicz, Jeszcze raz strukturalizm (sytuacja orientacji strukturalno-semiotycznej w etnologii polskiej 1972-1983), „Etnografia Polska” 1984, t. XXVIII, z. 2, s. 39. 
(pojęcie faktu społecznego), Ferdinanda de Saussure'a ${ }^{5}$, Marcela Maussa (zasada wymiany jako fakt społeczny, różne „poziomy” wymiany), Franza Boasa (dyrektywa docierania do nieuświadomionego poziomu zjawisk kulturowych) oraz tezach praskiego strukturalizmu lingwistycznego Mikołaja Trubeckiego i Romana Jacobsona (badania fonologiczne) ${ }^{6}$. Zdaniem Lévi-Straussa kulturę można badać za pomocą metod, jakie stosuje się w lingwistyce strukturalnej, ponieważ kultura jest efektem symbolizacji/strukturyzacji rzeczywistości przyrodniczej (naturalnej), jakiej dokonuje umysł człowieka przy pomocy języka. Kluczowym sposobem ujmowania rzeczywistości przyrodniczej jest tworzenie opozycji binarnych.

Historycy idei podkreślają, iż w humanistyce XX w. miała miejsce „moda na strukturalizm”. Strukturalizm, ze względu na systemowe ujmowanie zjawisk, jawił się jako szansa na „unaukowienie" humanistyki, zbliżenie jej do ideału nauk ścisłych. Jakkolwiek złoty okres tego kierunku badawczego najprawdopodobniej już minął, strukturalizm nadal znajduje swoich kontynuatorów. Kierunek ten wyraźnie wpłynął na rozwój badań teoretycznoliterackich. O randze strukturalizmu świadczy i ten fakt, że w nawiązaniu do niego utworzono nazwę kolejnej (i jednocześnie wyraźnie skierowanej przeciwko tezom strukturalistów) orientacji badaw-

${ }^{5}$ Dychotomia langue i parole jako dwóch odrębnych płaszczyzn analizy semiologicznej; ogłoszenie w 1916 r. Kursu językoznawstwa ogólnego de Saussure'a uważa się za symboliczny początek strukturalizmu.

${ }^{6}$ Zob. Słownik etnologiczny: terminy ogólne, red. Z. Staszczak, Państwowe Wydawnictwo Naukowe, Warszawa-Poznań 1987, s. 332.

${ }^{7}$ M. Czeremski, Struktura mitów. W stronę metonimii, Wydawnictwo Nomos, Kraków 2009, s. 7. 
czej w humanistyce: poststrukturalizm ${ }^{8}$. Niektórzy badacze uważają, iż od strukturalnego myślenia niepodobna się wyzwolić, i każda próba ujmowania zjawisk kultury de facto jest jakimś rodzajem strukturalizmu. Wydaje się, iż fakty te stanowią dostateczne uzasadnienie przyjrzenia się niektórym zagadnieniom klasycznego strukturalizmu z perspektywy meta. Próba ta może wydać się tym bardziej interesująca, iż filozoficzna refleksja metodologiczna nad naukami humanistycznymi pozostaje mniej rozwinięta i określona niż refleksja nad metodą nauk ścisłych.

\section{2. „ROZPRAWA O METODZIE” EDMUNDA LEACHA}

Edmund Leach swoje badania opisane w tekście Przeciw podziałowi na gatunki: czy przypowieści stawiaja światło na świeczniku, czy ukrywaja je pod korcem? określa mianem „badań strukturalnych”, „studiów strukturalnych” oraz „analizy strukturalnej”. Natomiast tytuł tomu, z którego pochodzi omawiany tekst, sugeruje, iż mamy do czynienia ze „strukturalistycznymi interpretacjami”. Leach nie uściśla, które z wymienionych określeń (zwłaszcza: „analiza” i „interpretacja”) najlepiej oddaje charakter obranego przez niego podejścia. Można przypuszczać, iż kryje się za tym przekonanie, iż w badaniach humanistycznych operacje opisywane tymi pojęciami są po części tożsame.

Antropolog ma świadomość, iż zasadnicze postulaty metody strukturalnej są w naukach humanistycznych rozwijane i realizowane na rozmaite sposoby. Za przykład daje prace Rudolfa Bultmanna, Claude’a Lèvi-Straussa, Rolanda Barthesa i Włodzimierza

${ }^{8}$ Zob. M. Głowiński, Posłowie, [w:] T. Hawkes, Strukturalizm i semiotyka, przeł. I. Sieradzki, Państwowe Wydawnictwo Naukowe, Warszawa 1988, s. 213.

${ }^{9}$ E. Leach, Przeciw podziałowi..., s. 128. 
Proppa. Leach zdaje sobie sprawę, iż proponowany przez niego wariant badań strukturalnych jest „zadłużony” u innych badaczy, ale jednocześnie nie spełnia w całości postulatów któregokolwiek z nich. $\mathrm{W}$ tym sensie mamy do czynienia $\mathrm{z}$ autorską propozycją Leacha. Głównym terminem stosowanym $\mathrm{w}$ metodologii Leacha jest struktura. Marginalnie pojawia się także określenie trans formacje strukturalne. Przez strukturę Leach rozumie pewien poziom znaczenia $\mathrm{w}$ tekście ${ }^{10}$, „tajemnice, tzn. ukryte znaczenia odmienne od rzucających się w oczy”, ,ustrukturyzowane uwzorowanie" tekstu ${ }^{11}$, „tematyczny wzór” w tekście ${ }^{12}$. „Transformacje strukturalne” są, jak się wydaje, różnymi, choć nie pozbawionymi podobieństw, konkretnymi realizacjami struktury w postaci fragmentów tekstu. Na ogół transformacje strukturalne nie są tym samym, co gatunki literackie wyróżniane przez teoretyków literatury ${ }^{13}$.

Leach twierdzi, iż struktura tekstu biblijnego nie jest wynikiem świadomej działalności jego autorów, jakkolwiek jakoś wynika $\mathrm{z}$ ideologii wczesnego Kościoła ${ }^{14}$. W innym miejscu antropolog pisze, iż właściwe strukturalne rozumienie tekstu biblijnego najprawdopodobniej było dane pierwotnym użytkownikom tekstu ${ }^{15}$. Natomiast dla współczesnych czytelników, uwikłanych w rozmaite sposoby interpretowania Biblii, ten poziom rozumienia jest nieznany. Strukturalista, badając tekst biblijny, działa jak „mistrzowie podejrzeń": odsłania ukrytą strukturę znaczeniową tekstu.

\footnotetext{
${ }^{10}$ Zob. tamże, s. 122.

${ }^{11}$ Tamże, s. 128.

${ }^{12}$ Tamże, s. 121.

${ }^{13}$ Tamże, s. 122.

${ }^{14}$ Tamże.

${ }^{15}$ Tamże, s. 147.
} 
Podstawowa teza Leacha charakteryzująca jego strukturalne podejście do tekstu biblijnego dotyczy właściwej relacji tego tekstu do rytuału eucharystycznego. Według Leacha „pozornie epizodyczny tekst Ewangelii powinien być rozpatrywany jako całość wyrażająca sens liturgii eucharystycznej"16. Badacz stwierdza, iż niewiele wiemy na temat obrządku pierwszych chrześcijan, oprócz tego, iż wykorzystywano w nich teksty ewangeliczne. Jednak w jego przekonaniu można sensownie założyć, iż zachodzą liczne podobieństwa pomiędzy wczesnym Kościołem a innymi wspólnotami religijnymi, wyrosłymi w tym samym czasie z pnia judaizmu. 0 tych ostatnich wiemy z kolei znacznie więcej. Leach przypomina, iż w wielu wspólnotach religijnych malowidła ścienne o tematyce religijnej objaśniały sens ich rytuałów. Tymczasem pierwsi chrześcijanie byli prawie nieikoniczni (z powodu zakazów tak religijnych, jak politycznych). Można się więc spodziewać, że ich święte teksty - obrazowe i epizodyczne - spełniały funkcję objaśniającą względem ich rytuału, czyli liturgii eucharystycznej. „Zakładam, że ów kontekst stosowania owych tekstów miał wpływ na sposób ich rozmieszczenia, a przynajmniej w pewnym stopniu na ich rzeczywistą zawartość"17. Leach podaje przykłady innych kultur (Kachinowie z północnej Birmy, lud Iban z Borneo, buddyjscy Syngalezowie ze Sri Lanki), gdzie, jego zdaniem, święty tekst pełnił podobną funkcję.

Leach podejmuje tradycję antropologiczną, która wszystkie święte teksty, niezależnie od kultury, w której powstały, oraz ich natury, określa mianem „mitu”. Mit to święta opowieść, systematycznie odtwarzana $\mathrm{w}$ rytuale, która nie musi być prawdziwa w sensie historycznym, lecz w sensie aksjologicznym. $\mathrm{Z}$ antropo-

\footnotetext{
${ }^{16}$ Tamże, s. 120.

${ }^{17}$ Tamże, s. 121.
} 
logicznego punktu widzenia, stwierdza Leach, chrześcijaństwo i jego święte księgi, podobnie jak wszelkie inne zjawiska religijne, można badać w powiązanych ze sobą kategoriach rytuał - mit, dzięki czemu nie stawia się ich w uprzywilejowanej pozycji, o co można by posądzać z ducha przecież europejską antropologię. W oparciu o tę zasadę heurystyczną antropologii Leach proponuje holistyczny postulat hermeneutyczny, aby traktować tekst biblijny jako znaczeniową całość, w której poszczególne fragmenty nie posiadają autonomicznego znaczenia: całość tekstu jest jednym mitem, poszczególne fragmenty, pozornie różne, w istocie mówią o tym samym. Przestrzeń i czas mityczny nie są tożsame z przestrzenią i czasem w znaczeniu historycznym, są , ,absolutnym tu i teraz". Stąd, zdaniem Leacha, mit:

nie ma początku, środka ani końca - wszystko istnieje jednocześnie jak w marzeniu sennym [...]. Kolejność wydarzeń w opowieści jest produktem ubocznym istoty narracji. Tekst może powiedzieć tylko jedną rzecz naraz, ale to co powie później, będzie jak można się spodziewać, identyczne z tym, co powiedział, lecz przy zastosowaniu innego obrazowania ${ }^{18}$.

Jednak warto zauważyć, że w praktyce badawczej Leach wyznacza granice tak rozumianej całości: mitologiczną całością są ewangelie, a nie np. Nowy Testament, Biblia czy Biblia wraz ze znanymi tekstami niekanonicznymi. Leach uzasadnia ten zabieg charakterem potocznej wiedzy religijnej: potocznie wydarzenia ewangeliczne znamy jako kompilację czterech ewangelii, a nie w podziale na poszczególne ewangelie.

${ }^{18}$ Tamże, s. 129-130. 
W związku z holistyczną koncepcją mitu Leach odrzuca tradycyjny podział tekstu Ewangelii na gatunki. Twierdzi, że podział ten jest pochodną instytucjonalnego podziału specjalizacji badawczych naukowców i de facto niewiele mówi na temat znaczenia samego tekstu. Kategoria mitu skutecznie znosi te podziały i pozwala na świeże spojrzenie na badany tekst.

Holistyczna kategoria interpretacyjna mitu nie tylko nakazuje traktować tekst całościowo, lecz również nakazuje traktować poszczególne fragmenty tego tekstu jako znaczeniowo (tzn. strukturalnie) tożsame z całością. Mówiąc inaczej, fragment tekstu religijnego wyraża to samo strukturalne znaczenie (tę samą mityczną strukturę znaczeniową) co tekst jako całość. Takie podejście pozwala Leachowi poddawać strukturalistycznym badaniom fragmenty Ewangelii, w tym fragmenty wyróżnione jako odrębne gatunki literackie, a nie tylko Ewangelię jako całość.

W sposób szczególny Leach wskazuje na mityczny (holistyczny) sens literackiego gatunku przypowieści ewangelijnych. W przypadku Ewangelii obok zwykłej narracji - „powieści” - wyróżniającym się gatunkiem literackim jest przypowieść. Brytyjski antropolog zwraca uwagę na fakt, iż samo znaczenie terminu „przypowieść nowotestamentowa" jest nieoczywiste. Leach twierdzi, iż jakkolwiek na ogół zwykliśmy uważać przypowieści za barwne historie o prostym przesłaniu, którego wydobycie utrudnia nam jedynie dystans czasowy i kulturowy, to w samym Piśmie Świętym jest wyraźnie powiedziane, że „przypowieści są tajemnicami, których znaczenie wyjawiane jest jedynie wybranym, a więc tym samym są niezrozumiałe dla tłumu" ${ }^{19}$.

Zapewne Leach nawiązuje do następującego fragmentu Ewangelii wg św. Marka:

${ }^{19}$ Tamże, s. 125. 
A gdy był sam, pytali Go ci, którzy przy Nim byli, razem z Dwunastoma, o przypowieść. On im odrzekł: „Wam dana jest tajemnica królestwa Bożego, dla tych zaś, którzy są poza wami, wszystko dzieje się $w$ przypowieściach, aby patrzyli uważnie, a nie widzieli, słuchali uważnie, a nie rozumieli, żeby się nie nawrócili i nie była i m odpuszczona [wina]" (Mk 4, 10-12)

oraz do następującego fragmentu z Ewangelii wg św. Łukasza:

Wam dano poznać [wprost] tajemnice królestwa Bożego, innym zaś w przypowieściach, aby patrząc, nie widzieli, i słuchając, nie rozumieli $( \pm k 8,10)$.

Z drugiej strony Leach chyba pomija pozornie podobne słowa w Ewangelii wg św. Mateusza:

Przystąpili do niego uczniowie i zapytali: „Dlaczego mówisz do nich w przypowieściach?” On im odpowiedział: „Wam dano poznać tajemnice królestwa niebieskiego, im zaś nie dano. [...] Dlatego mówię do nich w przypowieściach, że patrząc, nie widzą, i słuchając, nie słyszą ani nie rozumieją. Tak spełnia się na nich przepowiednia Izajasza: Słuchać będziecie, a nie zrozumiecie, patrzeć będziecie, a nie zobaczycie. Bo stwardniało serce tego ludu, ich uszy stępiały i oczy swe zamknęli, żeby oczami nie wiedzieli ani uszami nie słyszeli, aby swym sercem nie rozumieli, i nie nawrócili się, abym ich uzdrowił" (Mt 13, 10-11; 14-15)

${ }^{20}$ Wszystkie przytaczane przeze mnie cytaty z Biblii pochodzą z Biblii Jerozolimskiej 2004, podkreśl. A.S.-M. 
Problem interpretacji w naukach humanistycznych...

i dalej: „Otworzę usta w przypowieściach, wypowiem rzeczy ukryte od założenia świata" (Mt 13, 35). Te ostatnie fragmenty można sensownie zinterpretować, przeciwnie do Leacha, w kluczu rozumienia przypowieści jako opowieści, która w obrazowej i prostszej formie podaje to, co podane wprost, jest niezrozumiałe dla tłumu.

Założenie Leacha o wtórności mitu wobec rytuału prowadzi do pytania, co Leach rozumie mówiąc o „wyrażaniu sensu rytuału przez mit". Leach zakłada, że zdarzenia opisywane w micie są przypadłościowe, zaś jego istotę stanowi struktura, i to ona wyraża rytuał ${ }^{21}$.

Tego typu „ekspresyjna” zależność mitu od rytuału wyznacza dwie możliwe $\mathrm{z}$ logicznego punku widzenia drogi badania strukturalistycznego. W pierwszym przypadku badanie to można pomyśleć jako analizę tekstu Ewangelii w celu wydobycia ukrytej struktury mitycznej i odkrycia rytuału, który za tym mitem się kryje i jest przezeń wyrażany. $\mathrm{W}$ drugim przypadku sytuacja badawcza jest odwrotna. Z góry, a priori, zakłada się charakter rytuału, jaki wyrażany jest w tekście implicite w postaci ukrytej struktury mitycznej.

Niewątpliwie pierwsze podejście, które można określić jako autentycznie heurystyczne, byłoby o wiele bardziej ambitne poznawczo. Podejście drugie, czysto hermeneutyczne, ogranicza się do wykazania, że konkretny tekst da się zinterpretować w arbitralnych, apriorycznych kategoriach antropologicznych ${ }^{22}$.

${ }^{21}$ To ostatnie założenie posiada duże ograniczenie, ponieważ odrzuca możliwość rozpatrywania konkretnych wydarzeń, tworzących mit, w oderwaniu od postulowanej struktury mitu.

${ }^{22}$ Zagadnienie to, jako stricte metodologiczne, zostanie rozwinięte w ostatniej części artykułu. 
Leach opowiada się za drugim, czysto hermeneutycznym podejściem do analizy strukturalistycznej. Po pierwsze, uznaje a priori, co zostało już powiedziane wyżej, że tekst Ewangelii stanowi mitologiczną artykulację rytu eucharystycznego. Po drugie, Leach proponuje, aby teksty Ewangelii badać przy użyciu koncepcji rites de passage (obrzędów/rytuałów przejścia) Arnolda van Gennepa. „Badać” znaczy sprawdzić, czy schemat van Gennepa pozwala na wydobycie mitycznej struktury Ewangelii. Już na wstępie Leach określa tę koncepcję jako „teorię zadziwiająco przystającą do faktów" obrzędowych i cieszącą się dużym uznaniem ze strony antropologów ${ }^{23}$. Samo to stwierdzenie pozwala ocenić metodologiczną wartość analiz Leacha.

Wedle koncepcji van Gennepa, spośród rozmaitych sekwencji należy wyróżnić kategorię rytuałów przejścia. „Można je podzielić na następujące podkategorie: rytuały wyłaczenia (separacji), rytuały okresu przejściowego (marginalnego) i rytuały włączenia (integracji)"24. Sensem tych rytuałów jest bezpieczne tj. możliwie wolne od złych mocy (dla „zainteresowanego" i jego otoczenia) i zakończone jednoznacznym określeniem nowego statusu, przeprowadzenie człowieka z jednego świata do innego. Za klasyczny przykład obrzędów przejścia mogą służyć rytuały wejścia w dorosłość, zaślubiny, święcenia kapłańskie oraz koronacja królów, ciąża i poród, pogrzeb. Zdaniem francuskiego folklorysty, w wymienionych ceremoniach poszczególne podkategorie mogą być bardziej bądź mniej rozwinięte np. rozbudowany rytuał włączenia w przypadku zaślubin, długi okres przejściowy w przypadku ciąży, podkreślenie momentu wyłączenia w przypadku pogrzebu.

${ }^{23}$ E. Leach, Przeciw podziałowi..., s. 130.

${ }^{24}$ A. van Gennep, Obrzędy przejścia, przeł. B. Biały, Państwowy Instytut Wydawniczy, Warszawa 2006. 
Problem interpretacji w naukach humanistycznych...

Co więcej, niekiedy schemat ten ulega podwojeniu. Dzieje się tak zwłaszcza wtedy, gdy okres przejściowy między jednym stanem a drugim jest na tyle długi, by stworzyć odrębny etap. W ten właśnie sposób narzeczeństwo staje się okresem przejściowym między stanem wolnym a małżeństwem. Jednakże przejście od stanu wolnego do narzeczeństwa obejmuje całą serię specyficznych rytuałów wyłączenia, okresu przejściowego oraz integracji z okresem przejściowym. Z kolei przejście od narzeczeństwa do małżeństwa to seria rytuałów, począwszy od wyłączenia $\mathrm{z}$ okresu przejściowego, poprzez rytuały okresu przejściowego, aż po rytuały włączenia ${ }^{25}$.

Van Gennep ma świadomość braku pełnej adekwatności proponowanego schematu pojęciowego w odniesieniu do symbolicznej rzeczywistości człowieka: „Muszę jednak przyznać, że w wypadku działań ludzkich sklasyfikowanie tych rytuałów w możliwie jasny sposób nie może być tak precyzyjne jak na przykład podziały w botanice"26. Ma on ponadto świadomość, iż tego typu ogólność proponowanego przez niego schematu sprawia, iż schemat ten można stosować bez żadnej różnicy do szerokiej grupy zjawisk. Zauważa to również Leach: „[...] analiza w stylu van Gennepa jest tak redukcjonistyczna, iż przy odrobinie pomysłowości może być dopasowana do prawie każdej empirycznej sekwencji obrzędowej" ${ }^{27}$. O ile jednak pierwszy badacz uważa to za istotne ograniczenie, o tyle drugi widzi w tym mocną stronę proponowanego schematu.

Co więcej, wbrew tym słowom Leacha, van Gennep uznaje ograniczoną stosowalność (brak uniwersalności) proponowanego przezeń schematu: „Daleki jestem od twierdzenia, że wszystkie

\footnotetext{
${ }^{25}$ Tamże, s. 37.

${ }^{26}$ Tamże.

${ }^{27}$ E. Leach, Przeciw podziałowi..., s. 131.
} 
obrzędy związane z narodzinami, inicjacją, małżeństwem itp. mają charakter tylko i wyłącznie rytuałów przejścia"28. Etnolog wskazuje na takie aspekty wymienionych ceremonii jak: rytuały płodności, wróżbiarskie, opiekuńcze i inne.

Odmienna ocena wartości heurystycznej schematu rites de passage przez jego autora i przez Leacha stanowi cenną wskazówkę dla oceny wartości metodologicznej rozwiązania Leacha. Zagadnienie to zostanie podjęte w rozdziale ostatnim. Analizy metodologiczne poprzedzić musi jednak analiza konkretnego przykładu zastosowania przez Leacha jego koncepcji metody strukturalnej.

\section{BADANIA STRUKTURALNE EDMUNDA LEACHA}

Leach proponuje rozważyć, czy schemat van Gennepa da się dopasować do (przypadkowo) wybranych partii tekstu (czy lepiej: mitu) ewangelicznego. Punktem wyjścia analizy strukturalnej są opisy cudów z pierwszego rozmnożenia chleba, obecne we wszystkich czterech Ewangeliach (Mt 14, 13-21; Mk 6, 32-44; Łk 9, 10-17; J 6, 9-13) oraz opisy cudów z drugiego rozmnożenia chleba, zawarte w Ewangeliach wg św. Mateusza i wg św. Marka (Mt 15, 32-38; Mk 8, 1-9). Leach zwraca uwagę na fakt, iż liczni komentatorzy Biblii skłonni są wszystkie te opisy odnosić do jednego wydarzenia, lecz gubią się w argumentacji, dlaczego dwóch spośród ewangelistów opisuje tę samą historię aż dwa razy. Analiza strukturalna, dokonywana przez brytyjskiego antropologa, ma dostarczyć na to pytanie dostatecznej odpowiedzi.

\footnotetext{
${ }^{28}$ A. van Gennep, Obrzędy przejścia..., s. 37.
} 
Problem interpretacji w naukach humanistycznych...

Rozdział szósty Ewangelii wg św. Marka - opis pierwszego rozmnożenia chleba w kontekście opisów wydarzeń następujących tuż przed nim oraz tuż po nim - jest, zdaniem Leacha, modelowym przykładem tekstu o szkielecie typu rites de passage ${ }^{29}$. Postacią, która podlega rytuałom przejścia, jest Jezus Chrystus. (Marginalnie Leach wskazuje również na przemiany apostołów). Leach akcentuje trzy momenty opowieści ewangelicznej:

1) niemożność czynienia cudów; stopniowe odchodzenie Chrystusa od normalnego rodzinnego otoczenia,

2) cudowne rozmnożenie żywności oraz chodzenie po wodzie (epifania) ${ }^{30}$

3) powrót Chrystusa do normalnego rodzinnego otoczenia ale ze zdolnością czynienia cudów; jako osoby boskiej.

Wskazane przez badacza węzłowe zagadnienia niewątpliwie są zakorzenione w tekście biblijnym, a nadto wydają się odpowiadać schematowi zaproponowanemu przez van Gennepa: wyłączenie stan marginalny - włączenie. Leach stara się, aby wszystkie wydarzenia, opisane w rozdziale szóstym Ewangelii wg św. Marka, uporządkować według van gennepowskiej struktury. W rezultacie uzyskuje następujący schemat ${ }^{31}$ :

${ }^{29}$ Rozważaniom na temat tego, co uznaje Leach za strukturę tekstów ewangelicznych - schemat van Gennepa czy jednak pewną jego egzemplifikację poświęcam fragment ostatniego rozdziału niniejszego artykułu.

${ }^{30}$ Leach przez „epifanię” rozumie „kroczenie Jezusa po wodzie” lub „przemienienie Jezusa na górze”. Natomiast ja w dalszej części niniejszego tekstu decyduję się określać mianem epifanii wszystkie działania Chrystusa, przez które wyraża się jego nadnaturalna moc. Do problemu definiowania epifanii przez Leacha powracam w ostatniej części niniejszego artykułu.

${ }^{31}$ E. Leach, Przeciw podziałowi..., s. 136. 
stan marginalny;

inny świat

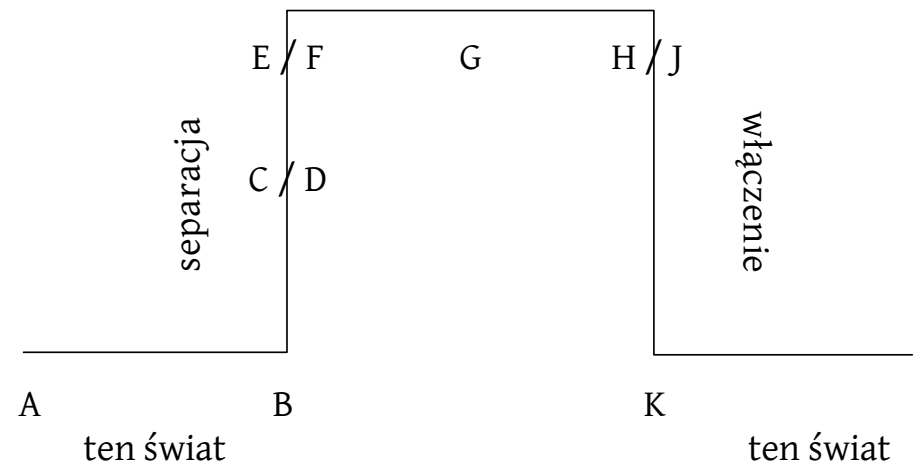
A - wzmianka o braku mocy Jezusa w jego domowym otoczeniu;
B - uczniowie wyruszają jako kapłani w anormalnej odzieży;
C - wzmianka o Jezusie jako następcy Jana Chrzciciela;
D - wzmianka o egzekucji Jana Chrzciciela (jako ofiary);
E - odejście Jezusa i uczniów do miejsca odosobnienia;
F - po którym następuje zgromadzenie wiernych;
G - cudowne pożywienie zgromadzonych (Eucharystia);
$\mathrm{H}$ - powrót uczniów do normalności (odwrócenie E);
I - odejście Jezusa do bardziej oddalonego miejsca odosobnienia;
J - epifania: Jezus objawia się jako osoba boska;
$\mathrm{K}$ - Jezus manifestuje boską moc w normalnym otoczeniu. 
Analiza Leacha, choć uwzględnia wszystkie wydarzenia opisane w omawianym fragmencie Biblii, może wzbudzać wątpliwości. Badacz klasyfikuje stosunkowo długi passus Ewangelii, opisujący porównanie Chrystusa do Jana Chrzciciela oraz zgładzenie tego drugiego, jako etap rytu separacji (Chrystusa i ewentualnie także jego uczniów). Jakkolwiek śmierć jest rodzajem separacji, to wydaje się, iż nie jest to separacja w tym znaczeniu, jakie przypisuje się jej w zaproponowanym przez Leacha wariancie van gennepowskiego schematu. A zatem można zaryzykować uwagę, iż Leach nie wyjaśnia w godny zaakceptowania sposób, dlaczego passus poświęcony Janowi Chrzcicielowi znalazł się $\mathrm{w}$ analizowanej opowieści biblijnej. Czyżby chodziło o jakiś rodzaj mnemotechniki, stosowanej przez tych, którzy opowiadali mity w czasie sprawiania obrzędów?

Kolejne ewangelie prezentują transformacje strukturalne omawianego mitu. Wersja św. Mateusza (Mt 14) wykazuje niewiele różnic w stosunku do wersji św. Marka.

Wersja św. Łukasza (Łk 8, 19-9, 45), choć zbliżona, wykazuje znaczące różnice. Więcej uwagi poświęca Łukasz przemianie świadomości uczniów aniżeli przemianie samego Chrystusa. Również epifania ma nieco inną postać: cudownego rozmnożenia chleba oraz przemienienia Chrystusa na górze (a także wcześniejszych: uciszenia burzy, uwolnienia opętanego Gerazeńczyka, uzdrowienia cierpiącej na krwotok i wskrzeszenia córki Jaira choć w zasadzie Leach pomija te fakty milczeniem). Jednak w opisie Chrystusa z omawianego fragmentu Ewangelii wg Łukasza, jak się wydaje, brakuje istotnych elementów z punktu widzenia schematu van Gennepa. Leach podkreśla, iż „cała sekwencja zaczyna się od «rytu separacji» $(8,22-25)$, kiedy to Jezus z uczniami płynie 
do obcej krainy" ${ }^{32}$, zaś nieco wcześniej czytamy słowa Jezusa o tym, iż jego matką i braćmi nie są (wyłącznie) matka i bracia biologiczni. Jest to prawdą, jednak Leach pomija milczeniem ewangeliczne informacje na temat cudów, dokonywanych przez Jezusa przed rzeczoną separacją (uzdrowienie sługi setnika, wskrzeszenie syna wdowy z Nain). Przejście, o którym Leach mówi, byłoby zatem jedynie przejściem fizycznym (ot, zwykła podróż), a nie przemianą „ontologiczną”. Jezus od początku omawianego fragmentu wykazuje nadludzką moc. Zaś przemiana świadomości uczniów również nie jest przemianą zupełną - tak na początku, jak na końcu omawianego fragmentu nie rozumieją rzeczy boskich.

Wersja św. Jana (6) obejmuje cudowne rozmnożenie chleba, kroczenie po morzu oraz mowę Jezusa w synagodze w Kafarnaum. Podobnie jak w przypadku Ewangelii wg św. Łukasza, Jezus już od początku wykazuje moc boską (wydarzenia opisane w rozdziale szóstym są poprzedzone m.in. uzdrowieniem chromego przy sadzawce Betesda). W pewnym sensie wszystkie te wydarzenia mają charakter epifaniczny. Leach pisze, iż mowa Chrystusa w synagodze ma charakter „niepełnej epifanii”: Jezus nawiązuje do "wczorajszego" cudownego rozmnożenia chlebów, nazywając siebie "chlebem życia” $(6,35)$. Wbrew sugestii Leacha także w tej wersji trudno dopatrzeć się „rytuałów przejścia”. Jedynie odnotowywany również przez Leacha fragment: „Czyż to nie jest Jezus, syn Józefa, którego ojca i matkę my znamy?” (6, 42a) może sugerować, iż wcześniej Chrystus nie wykazywał mocy nadprzyrodzonej.

W następnej kolejności antropolog, przy pomocy schematu van Gennepa i swoich dotychczasowych analiz, wyjaśnia, dlaczego Łukasz i Jan opisują tylko jedno cudowne rozmnożenie chleba,

${ }^{32}$ Tamże, s. 137. 
natomiast Marek i Mateusz dwa. Ze strukturalistycznego punktu widzenia rozmnożenie chleba jest wydarzeniem mitycznym; opisanie $\mathrm{w}$ micie dwóch rozmnożeń chleba jest de facto powtórzeniem tego samego motywu w kontekście dwóch transformacji strukturalnych. Przypomnijmy, iż Leach przez termin „epifania” rozumie objawienie boskiej mocy Chrystusa obecne w scenie kroczenia Chrystusa po wodzie lub przemienienia Chrystusa na górze. Ewangeliści, którzy opisują tylko jedną epifanię, opisują także tylko jedno rozmnożenie chleba ${ }^{33} \mathrm{i}$, odpowiednio, ewangeliści, którzy opisują obie epifanie, opisują dwa rozmnożenia chleba. Zdaniem Leacha jest to przejawem strukturalnego uwzorowania tekstów ewangelicznych. Jednak, i zaznacza to także Leach ${ }^{34}$, nie we wszystkich przypadkach realizowany jest pełny schemat van Gennepa.

Z dotychczasowych rozważań Leach wyciąga następujący wniosek:

Struktura, którą przedstawiłem, wzmacnia te elementy w tekście, które jasno zapewniają, że w dniu Sądu Ostatecznego (będącego także końcową Epifanią), zbawieni zostaną tylko ci, którzy stoją blisko Chrystusa, ponieważ uczestniczą w Eucharystii. I odwrotnie - zakłada się, że poprzez uczestnictwo w Eucharystii wierni zapewniają pojawienie się takiej Epifanii ${ }^{35}$.

${ }^{33}$ Leach pisze: „Łukasz i Jan opisują tylko jedną taką scenę, tj. Przemienienie, podczas którego Jezus chodzi po wodzie" (E. Leach, Przeciw podziałowi..., s. 140). Tymczasem Łukasz opisuje przemienienie na górze, zaś Jan kroczenie Jezusa po wodzie. Niestety, nie jestem w stanie sprawdzić, czy błąd w tekście Leacha jest błędem autora, czy też tłumacza.

${ }^{34}$ Tamże, s. 140.

${ }^{35}$ Tamże. 
Wydaje się, że wyprowadzenie takiego wniosku jest nadużyciem. Więcej piszę o tym problemie w ostatnim rozdziale niniejszego artykułu.

W następnej kolejności badacz rozważa problem przypowieści biblijnych. Jak już zostało powiedziane wcześniej, Leach nie baczy na tradycyjny podział na gatunki literackie, a także na odróżnianie w tekście narracji od wypowiedzi bohaterów, stąd założenie, iż „[...] nie ma wyraźnej różnicy między fragmentami tekstu, które zwyczajowo uważa się za przypowieści, a innymi, traktowanymi przez teologów jako teksty przedstawiające opowiedzianą historię" ${ }^{36}$. Szczególne zainteresowanie skupia antropolog na przypowieści o siewcy. W wersji Mateusza (Mt 12, 46-13, 52) przypowieść o siewcy poprzedzona jest wypowiedzią Chrystusa o jego odizolowaniu od rodziny, natomiast po serii przypowieści pojawia się informacja o powrocie Jezusa w rodzinne strony. Jakkolwiek nie ma tutaj relacji o epifanii, Leach uznaje, iż istnieje strukturalne podobieństwo pomiędzy przypowieścią o siewcy a opowieścią o cudownym rozmnożeniu chleba. Leach pisze:

Zgodnie z argumentacją strukturalistyczną można powiedzieć, że cała ta sekwencja jest swego rodzaju „ćwiczeniem” wprowadzającym do sekwencji dotyczącej Eucharystii/epifanii. W tym przypadku przypowieści i ich interpretacja powinny być równoważne w pewnym sensie względem opowieści o pożywieniu tłumu mistycznym ciałem Chrystusa. I to jest właśnie to, o czym ten tekst mówi ${ }^{37}$.

Przypowieść o siewcy umieszczona jest też $\mathrm{w}$ Ewangelii wg św. Marka i w Ewangelii wg św. Łukasza. Św. Jan nie przytacza tej przypowieści, za to $\mathrm{w}$ innym miejscu swej Ewangelii zapisuje

\footnotetext{
${ }^{36}$ Tamże.

${ }^{37}$ Tamże, s. 143.
} 
znamienne zdanie: „Zaprawdę, zaprawdę, powiadam Wam: Jeśli ziarno pszenicy, wpadłszy w ziemię, nie obumrze, zostanie samo jedno, ale jeśli obumrze, przynosi plon obfity" (J 12, 24). Zdaniem Leacha, fragment ten nawiązuje do przypowieści o siewcy, i łączy tę przypowieść z ideą Eucharystii: rytuału, sprawowanego przez Kościół, przy wykorzystaniu mitycznego tekstu - Ewangelii.

4. KRYTYKA PRACY LEACHA. STRUKTURALIZM LEACHA JAKO PRZYKEAD INTERPRETACJI/WYJAŚNIENIA

Celem niniejszego artykułu jest próba oceny z perspektywy metodologicznej strukturalistycznej propozycji Leacha. Nie chodzi przy tym, by oceniać strukturalizm jako taki, lecz jego konkretną wersję w wydaniu Leacha. Strukturalizm jako antropologiczna metoda interpretacji tekstu religijnego nie jest bynajmniej jednolitym nurtem hermeneutycznym. Propozycja Leacha posiada swoją specyfikę, której nie brak wewnętrznych ograniczeń. Ograniczenia te zamierzam pokazać w niniejszym rozdziale.

Proponowana przeze mnie krytyka będzie uwzględniała dwa aspekty: aspekt merytoryczny oraz logiczno-metodologiczny. Pierwszy dotyczy niekonsekwencji Leacha w stosowaniu metody strukturalnej analizy tekstu, drugi natomiast - ważniejszy - jego własnej oceny metodologicznej wartości proponowanej przezeń „metody” strukturalnej.

Pierwszy zarzut merytoryczny może dotyczyć pojęcia s t r u ktury, jakim posługuje się Leach w swej analizie Ewangelii. Jednym z celów tekstu Edwarda Leacha jest ukazanie struktury tekstu ewangelicznego. Zgodnie z deklaracją badacza, nadrzędnym celem jego pracy jest uzasadnienie tezy, iż nie ma różnicy 
pomiędzy gatunkami literackimi, składającymi się na Ewangelię, a „pozornie epizodyczny tekst Ewangelii powinien być traktowany jako całość wyrażająca sens liturgii Eucharystycznej" ${ }^{38}$. Aby uzasadnić tę tezę, Leach usiłuje wykazać istnienie w Ewangelii tematycznego wzoru, czyli struktury odpowiadającej schematowi „obrzędów przejścia”, zdaniem Leacha - opisującemu obrzęd Eucharystii. Ten sposób wyjaśniania wydaje się zgodny z tym, co o strukturalizmie pisze Gabriela Augustynowicz: ,[...] dotarcie do kodu - systemu [czyli struktury - A.S.-M.] wystarcza nam przy naszym wyjaśnianiu" ${ }^{39}$. Jednocześnie badacz proponuje, aby sprawdzić, czy struktura „rytuałów przejścia” autorstwa Arnolda van Gennepa "pasuje” do opowieści biblijnej. Zdaniem antropologa jego badania pokazują, iż konstrukt van Gennepa przystaje do struktury ewangelicznego tekstu. Ukryta struktura Ewangelii jest strukturą przejścia Chrystusa ze stanu wyrażania się na sposób ludzki do stanu wyrażania się na sposób boski (epifaniczny). Jest to jednocześnie struktura wyrażająca przemianę świadomości apostołów od świadomości ograniczonej do spraw ludzkich do stanu wtajemniczenia w sprawy boskie. Jednak w ostatecznej instancji - zgodnie z zasadą ekspresji rytuału przez mit - struktura mitu ewangelicznego ukazuje przejście wiernych, sprawujących rytuał Eucharystii, ze stanu poczucia braku do stanu spełnienia: obcowania z Bogiem, zbawienia. Jakkolwiek Leach określa swe badania mianem strukturalnych, i jakkolwiek uznaje, iż struktura van Gennepa "przystaje” do badanych tekstów, to jednak nie określa explicite, co de facto jest rzeczoną strukturą Ewangelii. Jest nią albo sam abstrakcyjny schemat van Gennepa, albo mniej abstrakcyjna egzemplifikacja tego schematu: przejście Chrystusa ze

\footnotetext{
${ }^{38}$ Tamże, s. 120.

${ }^{39}$ G. Augustynowicz, Jeszcze raz..., s. 37.
} 
Problem interpretacji w naukach humanistycznych...

stanu ludzkiego do boskiego. Tekst Leacha nie daje podstaw do dokonania wyboru pomiędzy tymi dwiema interpretacjami.

Drugi problem dotyczy wyboru przez Leacha narzędzia badawczego, jakim jest schemat rites de passage van Gennepa, w celu analizy Ewangelii. Schemat ten powstał wskutek obserwacji klasycznych obrzędów - od narodzin po śmierć, jakie towarzyszą ludziom różnych kultur w trakcie ich życia. Co więcej, w większości przypadków chodziło o obrzędy przejścia, jakie konkretny człowiek mógł doświadczyć w odniesieniu do siebie tylko jeden raz. Tymczasem Leach, w ślad za niektórymi antropologami, uznał ów schemat za poręczne narzędzie do badania zjawisk kulturowych o innym charakterze. Zastosował koncepcję van Gennepa nie do rytuału, lecz do wielowątkowego, barwnego tekstu. W tym celu musiał dodatkowo założyć, że tekst Ewangelii stanowi w swej strukturze ilustrację obrzędów.

Van Gennep kierował się przekonaniem, że rzeczywistość kulturowa ma charakter procesualny, a wszelka próba uporządkowania jej w schemat nie uwzględnia jej autentycznego charakteru. Tekst, przeciwnie, jest statyczny i pozbawiony charakteru procesualnego. Takie przeniesienie struktury van Gennepa ma oczywiście swoją cenę. Wprawdzie Leach odnajduje w Ewangelii vangennepowską strukturę, ale za cenę zignorowania tych fragmentów, które zakłócają przejrzystość struktury. Z drugiej strony, w pewnych passusach tekstów Ewangelicznych badacz dostrzega tylko „część struktury”, np. jedynie ryt separacji. Nie może to nie rodzić pytania o wartość poznawczą wyników badań, w których tak dalece abstrakcyjna struktura, jak struktura van Gennepa, „pasuje” tylko częściowo. Dla van Gennepa schemat „obrzędów przejścia" pozbawiony któregokolwiek członu: wyłączenia, stanu marginalnego lub separacji, byłby najprawdopodobniej pozba- 
wiony jakiegokolwiek sensu. Wprawdzie tekst Ewangelii, wielowątkowy i barwny, stwarza nieograniczone możliwości interpretowania, trudno jednak uznać to za zaletę „metody” Leacha.

Kolejnym zarzutem, jaki można postawić badaniom Leacha, jest arbitralność w stosowaniu dosłownego i metaforycznego podejścia do tekstów ewangelicznych. 0 ile historię o rozmnożeniu chleba Leach skłonny jest przyjąć w jej warstwie dosłownej, o tyle w przypowieści o siewcy dopatruje się znaczeń innych niż te, które bezpośrednio wynikają z tekstu. Wbrew wywodom Leacha, nie wynikają one także z kontekstu: w passusie z przypowieściami schemat van Gennepa jest "wysoce niepełny”. Tego typu metodologiczna niekonsekwencja $\mathrm{w}$ interpretacji tekstu sprawia, iż Leach dość swobodnie zestawia ze sobą takie pojęcia jak „rozmnożenie chleba”, „ofiara”, „śmierć”, „Eucharystia” i takie pojęcia jak „epifania Przemienienia Pańskiego”, „epifania kroczenia Jezusa po morzu”, „Sąd Ostateczny” „zbawienie w Dniu Ostatecznym”, co zbliża go bardziej do krytykowanej przezeń metody tradycyjnej hermeneutyki biblijnej niż do ideałów strukturalistycznych.

Analogiczne zastrzeżenia można wysunąć $\mathrm{w}$ odniesieniu do użycia przez Leacha terminu „epifania”. Leach odnosi ten termin przede wszystkim do sytuacji przemienienia Chrystusa na górze oraz do sytuacji kroczenia Chrystusa po morzu. Wspomina także o "częściowej epifanii”, odnosząc to wyrażenie do mowy w synagodze w Kafarnaum, w której Chrystus zapowiada swą zbawczą moc, a także o „epifanii ostatecznej” - Sądzie Ostatecznym. Tego typu użycie terminu „epifania” ma sens, jeśli za epifanię boskości Chrystusa uzna się nie tylko Przemienienie na górze, ale, zgodnie z tradycją teologiczną, także inne momenty, w których Chrystus ujawnia swą moc nadprzyrodzoną - a zatem wszystkie dokonywane przez Chrystusa cuda i znaki. Zawężenie tego pojęcia, tak 
jak czyni to Leach, do ledwie kilku wydarzeń ewangelicznych byłoby sensowne, gdyby dało się wskazać na ich wspólny zakres znaczeniowy, wyróżniający je z szerszej grupy zdarzeń podobnych. Tymczasem trudno jest zrozumieć, co łączy wydarzenie Przemienienia i kroczenia po wodzie, i co jednocześnie wyróżniałoby je od np. cudownego rozmnożenia chleba czy cudownego uzdrowienia chorego.

Z punktu widzenia analizy logicznej metoda strukturalna Leacha, podobnie jak wszelki strukturalizm antropologiczny, jest przykładem rozumowania zwanego wyjaśnianiem. Według Zygmunta Hajduka ${ }^{40}$ wyjaśnianie jakiegoś zdania polega na poszukiwaniu jego racji w zbiorze zdań zarówno uznanych (przesłanki), jak i nie uznanych za prawdziwe (hipotezy). Zdanie wyjaśniane jest dedukowalne ze swych racji. Istnieją różne typy wyjaśniania: przez proste uogólnienie indukcyjne oraz wyjaśnianie teoretyczne. To ostatnie odwołuje się do pewnych terminów teoretycznych, oznaczających hipotetyczne, nieobserwowalne byty lub przyczyny mające za zadanie „wyjaśnić” obserwowane zjawisko (tekst, zdanie faktualne). Wśród typów wyjaśnień Hajduk wymienia osobno tzw. interpretację humanistyczną polegającą na porównaniu „obserwowalnego” zdarzenia humanistycznego ze zdarzeniem lub zjawiskiem typowym.

Niezależnie od typu wyjaśniania, rozumowanie to nigdy nie gwarantuje pewności. Każde zdanie jest dedukowalne z nieskończonej liczby innych zdań, zatem, teoretycznie rzecz ujmując, możliwych jest nieskończenie wiele różnych wyjaśnień tego samego zdarzenia (faktu) czy zdania (tekstu). Pojęcie prawdziwości

${ }^{40}$ Z. Hajduk, Ogólna metodologia nauk, Wydawnictwo Katolickiego Uniwersytetu Lubelskiego, Lublin 2000, s. 82 i n. 
nie znajduje tutaj zastosowania. Co więcej, niejednoznaczność wyjaśnienia „działa” również w drugą stronę: każde wyjaśnienie można „dopasować” do dowolnych faktów, także faktów negujących proponowane wyjaśnienie. $\mathrm{W}$ tym ostatnim wypadku często dokonuje się to przez odwołanie się do tzw. modyfikacji ad hoc. Jednakże ze względu na arbitralny charakter tych modyfikacji współczesna metodologia zakazuje tego typu procedur ${ }^{41}$.

Wyjaśnienie strukturalne należy potraktować raczej jako pewien typ wyjaśnienia teoretycznego niż interpretację humanistyczną w rozumieniu Hajduka. Struktura wyjaśniająca nie jest bowiem żadnym obserwowanym typowym zjawiskiem, lecz pewną hipotetyczną konstrukcją teoretyczną. T e o r e ty c z ny charakter schematu van Gennepa, stosowanego przez Leacha, wydaje się nie ulegać wątpliwości. Pewna abstrakcyjna struktura zostaje przeniesiona $\mathrm{z}$ jednego kontekstu do zupełnie innego, w sposób, który nie wydaje się oczywisty, a z punktu widzenia twórcy tego schematu (van Gennepa) wręcz niedopuszczalny.

Przenoszenie struktur wyjaśniających z jednego kontekstu do drugiego samo w sobie nie jest zakazane, gdyż może okazać się cennym narzędziem heurystycznym (tzn. odkrywczym). Wszelako, aby taki zabieg uznać za celowy i wartościowy powinniśmy dysponować przynajmniej minimalnymi obiektywnymi kryteriami oceny nowych hipotez wyjaśniających. Problem Leacha wydaje się polegać na tym, że jedyne kryteria, jakie proponuje w celu oceny zaproponowanej przezeń aplikacji schematu van Gennepa

${ }^{41} \mathrm{Na}$ temat relacji faktu do wyjaśniania por. P. Duhem, Teoria fizyczna. Jej przedmiot i struktura (fragmenty), [w:] Pierre Duhema filozofia nauki. Wybór pism, red. K. Szlachcic, przeł. M. Sakowska, Wydawnictwo Uniwersytetu Wrocławskiego, Wrocław 1991, s. 80-81; na temat modyfikacji ad hoc zob. A. Chalmers, Czym jest to, co zwiemy nauka?, przeł. A. Chmielewski, Wrocław 1993, s. 77-79. 
Problem interpretacji w naukach humanistycznych...

do interpretacji tekstu Ewangelii, to „zadziwiające przystawanie [schematu] do faktów" i duże uznanie ze strony antropologów.

Zgodnie z tym, co zostało powiedziane, samo „przystawanie” w żadnym wypadku nie świadczy o poznawczej wartości zastosowanego schematu. Można zapewne bez trudu wykazać, że wiele innych schematów także „pasuje” do Ewangelii. Swego czasu tego typu metoda „podobieństwa” dominowała w astrologii i magii: każde, dowolne podobieństwo wskazywało na jakieś ukryte związki i przyczyny. Dopiero na początku czasów nowożytnych zadano istotne $\mathrm{z}$ epistemologicznego punktu widzenia pytanie, które podobieństwa są istotne dla naszego poznania, a które są li tylko subiektywne i estetyczne ${ }^{42}$. Z tego pytania wyrosła współczesna nauka empiryczna. Samo uznanie przez innych antropologów nie wydaje się zbyt wartościowym argumentem, gdyż możliwe jest, że także oni kierują się podobnie subiektywnymi motywami jak Leach.

Z drugiej strony, przy odrobinie pomysłowości oraz zwłaszcza przy odpowiednich modyfikacjach ad hoc każdą teorię można dostosować do dowolnych faktów, a w przypadku interpretacji tekstu - do dowolnego fragmentu tekstu. Tak właśnie, jak pokazałam, postępuje Leach, dopasowując schemat do tekstu Ewangelii „na siłę": eliminując niewygodne szczegóły lub rezygnując z brakujących w tekście elementów schematu.

Leach fascynuje się „zaletą" schematu, iż można go zastosować do niemal wszystkich zachowań kulturowych, czyniąc z niej argument za wartością poznawczą tego schematu („prawdziwością”). Swoim zachowaniem przypomina wszakże krytykowanych przez Karla Rajmunda Poppera indukcjonistycznie nastawionych Marksa,

${ }^{42}$ Zob. Z. Liana, Okultyzm a nauka w okresie oświeceniowym, [w:] M. Heller et. al., Nauki przyrodnicze a teologia: konflikt czy wspótistnienie, Wydawnictwo OBI - Biblos, Tarnów 2001, s. 169-298. 
Freuda i Adlera, odnajdujących wszędzie „potwierdzenia” ich hipotez. Tego typu potwierdzenia świadczą jedynie o tym, że „każdy dający się pomyśleć przypadek może być zinterpretowany przez jego teorię [...] Ta rzekoma zaleta jest $\mathrm{w}$ istocie mankamentem"43.

Nie chodzi o to, by teorie antropologiczne traktować jak teorie empiryczne. Chodzi raczej o pewną dozę krytycyzmu w koncepcjach humanistycznych. Leach nie informuje, jakie niezgodności w tekście musiałyby zajść, aby jego wyjaśnienie strukturalne okazało się nieadekwatne $\mathrm{w}$ odniesieniu do Ewangelii. Tym samym wyniki jego badań są niekrytykowalne, co budzi obawę, iż mamy tu do czynienia nie tyle z metodą badawczą i jej realizacją, ile $\mathrm{z}$ ideologią. Pisałam, iż pod tym względem van Gennep był bardziej krytyczny od Leacha. Nie uważał, by „moc” interpretacyjna jego schematu - zdolność do dopasowania do dowolnych niemal zachowań kulturowych - była jego zaletą. Stąd całkiem świadomie nakładał na swój schemat dodatkowe ograniczenia stosowalności i wyrażał wątpliwości co do jego hermeneutycznej uniwersalności.

Ostatnia uwaga krytyczna dotyczy stosunku Leacha do innych metod badawczych. Jakkolwiek stara się on zachować neutralną postawę wobec rozmaitych metod badawczych, dość często atakuje inne podejścia niż strukturalne. Tym samym jednak wykracza poza uprawnienia antropologa. W niektórych partiach tekstu, zamiast zastosowania właściwej dla etnologii, a zaczerpniętej od Husserla, neutralnej ideologicznie procedury „brania w nawias” pewnych problemów badawczych w celu ograniczenia pola bada-

${ }^{43}$ K.R. Popper, Nauka. Domysty i refutacje, [w:] tenże, Droga do wiedzy. Domysty i refutacje, przeł. S. Amsterdamski, Państwowe Wydawnictwo Naukowe, Warszawa 1999, s. 64-65. 
Problem interpretacji w naukach humanistycznych...

nia, Leach wyraża słowa krytyki innych perspektyw badawczych, w szczególności podejścia historyczno-krytycznego:

Nie wierzę, że ktokolwiek dostrzega różnicę między poprawnymi i niepoprawnymi „interpretacjami” tekstów biblijnych. Na tym polu można fantazjować bez ograniczeń" ${ }^{44}$;

[...] absurdem jest próba rozróżnienia w obrębie dzisiejszych tekstów ewangelicznych passusów, które są utrwaleniem rzeczywistych słów realnej osoby, jaką był Jezus z Nazaretu oraz fragmentów, które reprezentują późniejsze głosy redakcyjne do tych słów ${ }^{45}$

i dalej:

Nie wierzę w ogóle, że Jezus był postacią historyczną. Dla mnie ma on dramatyczną, mityczną i poetycką realność Edypa Sofoklesa. Nawet jeśli kiedyś żył syn żydowskiego cieśli, który stał się prorokiem czasów Józefa, to i tak nie możemy się łudzić, iż będziemy cokolwiek o nim wiedziećt ${ }^{46}$.

Ten radykalny sceptycyzm, stosowany konsekwentnie, jak się wydaje, nie dopuszcza możliwości przeprowadzania jakichkolwiek badań historycznych i nie uznaje za zasadne żadnych innych metod interpretowania jakichkolwiek tekstów z przeszłości.

Sposób, w jaki Leach argumentuje za wartością strukturalnej metody interpretacji oraz za wyjątkowością strukturalnego znaczenia tekstu, ma charakter dalece arbitralny. Według Leacha metoda strukturalna „dostarcza zadowalającego wyjaśnienia”. Na rzecz jej „prawdziwości” świadczy z kolei to, że rozwiewa jak najwięcej wątpliwości interpretacyjnych, przy jednoczesnym braku

\footnotetext{
${ }^{44}$ E. Leach, Przeciw podziałowi..., s. 121.

${ }^{45}$ Tamże, s. 125.

${ }^{46}$ Tamże, s. 144.
} 
uwikłania w kontrowersyjne założenia i maksymalnym uproszczeniu problemu. Niemal wszystkie pojęcia zastosowane przez Leacha $\mathrm{w}$ celu uwiarygodnienia metody strukturalnej mają charakter subiektywno-psychologiczny: zarówno pojęcie zad o w olenia, jak i pojęcie rozwiania wątpliwości czy kontrowersyjności, a nawet prost oty nie są pojęciami metodologicznymi gwarantującymi intersubiektywną ocenę wartości stosowanej metody. Bliżej im do wewnętrznych kryteriów przynależności do grupy wyznawców określonego estetyczno-aksjologicznego paradygmatu (por. Kuhn) niż do uniwersalnych (intersubiektywnych) kryteriów prawdzi wości.

\section{ZAKOŃCZENIE}

Celem niniejszego artykułu było zbadanie z perspektywy metodologicznej propozycji strukturalistycznej Leacha, wyrażonej w jego tekście Przeciw podziałowi na gatunki: czy przypowieści stawiaja światto na świeczniku, czy ukrywaja je pod korcem?. Podstawowym pytaniem, na jakie próbowałam odpowiedzieć, brzmi: „Jaka jest wartość heurystyczna badań Leacha?".

Przedmiotem badań był strukturalizm Leacha, zarówno ten przezeń „deklarowany” jak i ten „realizowany” w jego analizach Ewangelii. Stąd usiłowałam również odpowiedzieć na pytanie o to, czy jego koncepcja może zostać uznana za spójną.

Powołując się na rozróżnienia zaproponowane przez Z. Hajduka, uznałam iż wywód Leacha należy potraktować jako przykład wyjaśniania teoretycznego, tj. takiego, które racji zdania poszukuje odwołując się do pewnych terminów teoretycznych, oznaczających hipotetyczne, nieobserwowalne byty. W przypadku Leacha takim terminem teoretycznym jest struktura . 
Leach, odwołując się do rozważań van Gennepa, strukturę tę utożsamia ze schematem „rytuałów przejścia” albo z pewną jego egzemplifikacją. Brytyjski antropolog, wbrew intencjom van Gennepa, nie stosuje tego schematu do rytuałów przejścia w klasycznym rozumieniu, lecz do tekstu ewangelicznego, uznając, że przez tekst ten wyraża się rytuał eucharystyczny. Leach deklaruje, iż odnajduje w Ewangelii elementy vangennepowskiego schematu, de facto - często kosztem zignorowania niewygodnych fragmentów Ewangelii lub pominięcia niektórych elementów schematu. Również, wbrew swym deklaracjom, łączy podejście dosłowne oraz alegoryczne do tekstu ewangelicznego, w sposób swobodny posługując się takimi terminami jak: „epifania”, „Królestwo”, „izolacja”.

Leach przyjmuje założenia typowe dla antropologów, traktując Ewangelię jako „mit” (zgodnie z etnologiczną definicją mitu). Jednak o ile rzetelni badacze mitu jedynie zawieszają rozważania historyczne, o tyle Leach na ogół zachowuje wobec tych rozważań (czy raczej prowadzących je badaczy) postawę krytykancką.

Wartość heurystyczna rozważań Leacha, jego zdaniem opiera się na „zadziwiającej przystawalności schematu do faktów”, "wzbudzaniu zadowolenia", poparciu innych antropologów. Są to czynniki psychologiczne, mało istotne z punktu widzenia metodologii nauk.

Niniejszy artykuł stanowi próbę zbadania z pozycji metodologicznej jedynie propozycji strukturalnej Edmunda Leacha. Ta zaś jest propozycją tyleż klasyczną, co stosunkowo wczesną. Można się spodziewać, iż współcześni kontynuatorzy badań strukturalnych z powodzeniem unikają błędów popełnionych przez Leacha.

$\mathrm{Z}$ drugiej strony, do niektórych spośród postawionych przeze mnie zarzutów (np. psychologizmu u Leacha) można odnieść się krytycznie, wskazując na ograniczenia samej metodologii. 


\title{
ON THE INTERPRETATION IN THE HUMANITIES (THE CASE OF STRUCTURALISM OF EDMUND LEACH)
}

\begin{abstract}
SUMMARY
The article presents the problem of structuralism in cultural anthropology as an example of interpretation in the humanities. The main goal is a critical description of Edmund Leach's proposal put forward in his Against Genres: Are Parables Lights Set in Candlesticks or Put Under a Bushel? The proposed method, as well as its application to biblical texts, is analysed from the perspective of philosophy of science. The analysis leads to the description of areas in which the author breaches the rules of the method proposed by himself.
\end{abstract}

\section{KEYWORDS}

structuralism, structure, structural transformation, the rites of passage, myth, rite, text, the Bible, the Gospels, parable, explanation, interpretation 